УДК $316+331.108$

DOI https://doi.org/10.32840/2707-9147.2020.86.11

М. В. ТУЛЕНКОВ

доктор соціологічних наук, професор, професор кафедри галузевої соціології

Київський національний університет імені Тараса Шевченка

B. П. БЕX

доктор філософських наук, професор, завідувач кафедри управління та євроінтеграції Національний педагогічний університет імені М. П. Драгоманова

\title{
ОРГАНІЗАЦІЙНО-УПРАВЛІНСЬКІ ВІДНОСИНИ У ФОКУСІ СОЦІОЛОГІЧНОЇ АНАЛІТИКИ
}

У статті в контексті системної соціологічної аналітики подається процес формування соціального потенціалу організаційно-управлінських відносин у сучасному перехідному суспільстві. Водночас визначаються принципові засади, змістовні параметри, функиіональний характер і специифічні особливості різноманітних типів організаційно-управлінських відносин, виокремлюються передумови та ключові сочіальні чинники концептуальної еволючії та розвитку цчих відносин, а також виявляються механізми функиіонування та відтворення певного типу організаційно-управлінських відносин у перебігу суб'єкт-об'єктної взаємодії у процесі різноманітної соціальної діяльності на різних рівнях соиіальної організації сучасного суспільства. Зокрема, аргументуються умови використання таких різновидів організаційно-управлінських відносин, як, наприклад, відносини керівництва та підпорядкування, субординації та координації, ичентралізму та самостійності, дисциилінованості та відповідальності тощо.

Визначено, щзо одним із головних видів організачійно-управлінських відносин є відносини централізму та самостійності, котрі перебувають між собою в нерозривній і суперечливій діалектичній єдності. Причому відносини централізму являють собою форму взаємозв'язку між суб 'єктами управління різних організаційних рівнів щуодо реалізації визначених функиій, за якого один суб'єкт управління (вищий) наділяється правами й повноваженнями визначати зміст і спрямованість діяльності іншого суб 'єкта управління (нижчого) відповідно до загальної управлінської мети, тобто відповідно до загального інтересу. Щодо відносин самостійності, то вони припускають наявність у суб' 'ктів організаційно-управлінських відносин таких прав, повноважень $i$ обов'язків, які дають їм можливість самим визначати зміст і спрямованість своєї діяльності. Якщо за відносин централізму вищий суб' 'кт організацій-

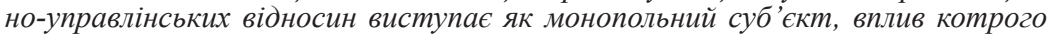
носить переважно односпрямований характер, то за відносин самостійності всі суб 'єкти, незалежно від рівня соціальної ієрархії, є рівноправними, тобто їхній взаємозв'язок будується на основі механізмів взаємоспрямованого організаційно-управлінського впливу одне на одного.

(C) М. В. Туленков, В. П. Бех, 2020 
У статті аналізується також практика застосування різних за типом організаційно-управлінських відносин у процесі функціонування соиіальних організацій у різних сферах суспільного буття, а також пропонуються відповідні рекомендації щзодо перебудови організаційно-управлінських відносин в умовах глобальних сочіально-економічних, політичних і соціокультурних змін, а також у перебігу суспільних трансформацій сучасного украӥнського соичуму на засадах принципів демократії та вільного ринку.

Ключові слова: зміст, особливості, характер $і$ потенціал організаційно-управлінських відносин, типологія та функиії організаційно-управлінських відносин, механізми становлення, функціонування, відтворення та розвитку організаційно-управлінських відносин.

Постановка проблеми. Актуальність проблеми визначення соціального потенціалу організаційно-управлінських відносин зумовлена, з одного боку, об'єктивними потребами істотної перебудови наявної системи соціального управління українського суспільства, а 3 іншого боку, динамічним розвитком теоретичних засад соціології управління як галузі сучасного соціологічного знання в умовах істотних глобальних економічних, політичних, соціальних і соціокультурних трансформацій, пов'язаних зі становленням та розвитком нової інформаційної цивілізації. Йдеться про широке розгортання соціологічних досліджень, спрямованих на вивчення складних організаційно-управлінських явищ і процесів, котрі стосуються управління суспільством та утворюють його систему. Тобто потрібне якісно нове розуміння сутнісних ознак організаційно-управлінських відносин на всіх рівнях соціальної організації сучасного суспільства [13, с. 3-4].

Аналіз розробленості теоретичних засад організаційно-управлінських відносин показує, що цій проблемі надається недостатня увага з боку соціологічної науки, незважаючи на те, що будь-які соціальні явища та процеси, які виникають у суспільстві, формуються, як правило, на основі організаційно-управлінських контактів, зв'язків і відносин між індивідами й соціальними групами. Причому особлива роль організаційно-управлінських відносин у розвитку сучасного суспільства постійно зростає завдяки їх всеохоплюючому характеру та активному впливу на впорядкування не тільки соціально-економічного, політичного й духовного життя суспільства, але і сталого функціонування й подальшого розвитку суспільної системи загалом.

У дослідженні організаційно-управлінських відносин, як показує аналіз, сформувалоськільканауковихпідходів, спрямованихнавивчення їх змісту, структури та тієї ролі, яку вони відіграють у життєдіяльності суспільства. Наприклад, у межах периого - соціологічного - nідходу організаційно-управлінські відносини розглядаються як визначальний структурний елемент усякого суспільства; в межах другого економічного підходу - вони трактуються як ключовий чинник ефек- 
тивності матеріального виробництва; в перебігу третього - nолітико-правового підходу - розуміються як інструментальна основа державного управління у співвідношенні з політичними і правовими відносинами, а в контексті четвертого - соціально-психологічного niдxодy - ці відносини становлять організаційну структуру формальних і неформальних стосунків і взаємодій керівників і підлеглих, тобто керуючих і керованих.

Це вказує на той факт, що й дотепер немає єдиної концепції організаційно-управлінських відносин, яка б не тільки сприяла формуванню організаційного потенціалу вітчизняних управлінських кадрів, але й поряд із цим виступала визначальним чинником упорядкування організаційно-управлінських взаємодій між керуючими суб'єктами різних ієрархічних рівнів у напрямі поглиблення демократичних перетворень та подальшого розвитку соціально орієнтованої ринкової економіки.

Мета статті. Головною метою цієї роботи є визначення сутності і змісту, а також з'ясування структури, типології та соціального потенціалу організаційно-управлінських відносин як ключового чинника підвищення ефективності соціального управління, спрямованого на реалізацію загального та особливих інтересів індивідів і соціальних груп у транзитному суспільстві.

Виклад основного матеріалу. Стале функціонування всякого суспільства нерозривно пов'язане з його здатністю завдяки власним саморегулятивним механізмам забезпечувати визначений порядок організаційної взаємодії людей, спрямованої на досягнення спільної мети. Причому дане суспільство як системне утворення складається 3 керуючих і керованих людей зі сталими організаційно-управлінськими зв'язками, які в сукупності з іншими елементами утворюють певну організаційну систему соціального управління, на яку покладається відповідальна місія - своєчасно та адекватно реагувати на виклики зовнішнього середовища та відповідно до цих, часто-густо непередбачуваних викликів, виробляти та впроваджувати інноваційні стратегії суспільного розвитку [14, с. 5].

3 огляду на це особливої ваги та значимості набувають організаційно-управлінські відносини, які об’єктивно складаються між людьми у процесі організації та здійснення будь-якої спільної діяльності, виступаючи водночас специфічною формою формально впорядкованих взаємозв'язків між ними [3, с. 524]. У ці відносини вступають не тільки ті люди, котрі професійно здійснюють певні організаційно-управлінські функції, але й ті, що беруть безпосередню участь у різній трудовій діяльності, оскільки кожний різновид спільної людської діяльності потребує визначених колективних дій заради досягнення спільної мети шляхом планування, організації, поділу між ними ролей, а також координації, мотивації й контролю за результатами тощо. Унаслідок цього, як свідчить аналіз, «суто управлінські відносини та їх нерозривна органічна частина - організаційні відносини - якби пронизу- 
ють усі види суспільних відносин (економічні, соціальні, політичні, духовні)» [5, с. 64].

Натомість організаційно-управлінські відносини, як свідчить аналіз, за своїм змістом є нічим іншим як постійно відтворюваним процесом взаємодії керуючих суб'єктів і керованих об'єктів (тобто індивідів і соціальних груп) щодо здійснення ними певних рольових функцій у певному виді людської діяльності, головним чином щодо вироблення, ухвалення та реалізації організаційно-управлінських рішень. А залежно від характеру цієї взаємодії індивідів і соціальних груп об'єктивно виникають різноманітні види організаційно-управлінських відносин, які в сукупності й утворюють їхню структуру. Водночас структура цих організаційно-управлінських відносин, а також їх видове різноманіття та взаємозв'язок визначаються, перш за все, соціальною структурою самого суспільства. Останнє являє собою складну соціальну систему, яка складається з різних форм і видів організаційно-управлінської взаємодії індивідів і соціальних груп у різних сферах суспільної життєдіяльності. Причому самі індивіди та соціальні групи володіють не тільки різноманітними соціальними якостями, але й визначеним соціальним положенням, що впливають на формування їх особливих інтересів у межах спільної діяльності. Тому з особливостей відтворення та розвитку самої суспільної системи об'єктивно й виникає необхідність виконання іiі підсистемою соціального управління певних організаційно-управлінських функцій, що й зумовлює існування відповідної структури організаційно-управлінських відносин [6, с. 18-20].

Водночас необхідно зазначити, що одним із головних видів організаційно-управлінських відносин є відносини цеентралізму та самостійності, які перебувають між собою в нерозривній і суперечливій діалектичній єдності. Причому відносини централізму являють собою форму взаємозв'язку між суб'єктами управління різних організаційних рівнів щодо реалізації визначених функцій, за якого один суб'єкт управління (вищий) наділяється правами й повноваженнями визначати зміст і спрямованість діяльності іншого суб'єкта управління (нижчого), відповідно до загальної управлінської мети, тобто відповідно до загального інтересу. Таке положення суб'єктів управління один щодо одного визначається, як правило, залежно від виконуваних ними загальних або часткових (приватних) організаційних функцій. Наприклад, відносини централізму існують між главою і членами уряду, а також між урядом і громадянами країни, причому кожний із цих соціальних суб'єктів (залежно від соціального статусу, тобто соціального положення в суспільстві) може бути один щодо одного як вищим, так і нижчим [19, с. 32-33].

Щодо відносин самостійності, то вони припускають наявність у суб'єктів організаційно-управлінських відносин таких прав, повноважень і обов'язків, які дають їм можливість самим визначати зміст i 
спрямованість своєї діяльності. Якщо за відносин централізму вищий суб'єкт організаційно-управлінських відносин виступає як монопольний суб'єкт, вплив котрого носить переважно односпрямований характер, то за відносин самостійності всі суб'єкти незалежно від рівня соціальної ієрархії є рівноправними, тобто їхній взаємозв'язок будується на основі механізмів взаємоспрямованого організаційноуправлінського впливу одне на одного. Такими суб'єктами організаційно-управлінських відносин у демократичному суспільстві $\epsilon$, зокрема, президент країни і парламент, між якими існують впорядковані відносини взаємоспрямованого впливу одне на одного в межах законодавчо визначених повноважень.

Водночас проведений аналіз засвідчує, що відносини централізму й самостійності розглядаються часто-густо 3 погляду їх функціонального змісту, тобто без урахування соціального аспекту цих відносин, який істотно впливає на формування особливих інтересів учасників організаційно-управлінських відносин [4, с. 60]. Однак без аналізу цих інтересів неможливо визначити роль і механізми впливу суб'єктів організаційно-управлінських відносин на формування змісту загальної мети. Зокрема, відносини централізму визначають не тільки загальну соціальну спрямованість організаційно-управлінської діяльності, але й ті межі, в рамках яких ця діяльність буде адекватно відповідати змісту загальних інтересів. Водночас відносини самостійності надають можливість у визначених межах кожному суб'єкту організаційно-управлінських відносин обирати свій власний, специфічний шлях руху, який відповідає їх особливим інтересам. Але відносини централізму та самостійності мають бути не тільки тісно взаємопов'язані між собою, але й окрім цього ще й ретельно збалансовані, оскільки чим більше прав, повноважень та обов'язків буде в одних суб'єктів організаційно-управлінських відносин, тим їх буде менше в інших суб’єктів цих відносин [8, с. 62].

Звідси випливає, що посилення централізму в системі організаційно-управлінських відносин означає підвищення іï монополізації, що, по-перше, суттєво звужує межі вибору суб'єктами цих відносин самостійного шляху руху, а по-друге, в такій централізованій системі відносин стає менше незалежних суб'єктів, оскільки централізм заснований на механізмах однобічного організаційно-управлінського впливу. Водночас посилення самостійності в цій системі приводить до розширення меж вільного вибору суб'єктами цих відносин свого специфічного шляху розвитку, що відповідає їх особливим інтересам. У цьому разі виникає, як правило, два суперечливих явища. 3 одного боку, розширюється поле для своєрідного розвитку суб'єктів організаційно-управлінських відносин, оскільки їх особливий інтерес одержує найбільшого відображення. А з іншого боку, знижується здатність організаційної системи управління до координації спільної діяльності та узгодження часто-густо не співпадаючих інтересів суб'єктів різних 
рівнів, оскільки кожний із них намагається розвиватись, з огляду на свої особливі інтереси. В результаті відбувається загострення протиріч між суб’єктами організаційно-управлінських відносин і порушується життєдіяльність суспільної системи загалом, а в разі їх крайнього загострення фактично відбувається й руйнування цієї системи.

Тому взаємозв'язок відносин централізму й самостійності в системі організаційно-управлінських відносин припускає обов'язкове встановлення ступеня їхньої відповідності між собою. Основною підставою для цього виступає необхідний характер єдності та незалежності особливих інтересів суб'єктів різних ієрархічних рівнів. Централізм у системі організаційно-управлінських відносинах $\epsilon$ виправданим лише тоді, коли він необхідний для збереження суспільства як цілісної системи, а також для визначення певних меж діяльності керуючих суб'єктів, які будуть забезпечувати взаємну орієнтацію на досягнення загальної суспільної мети. А самостійність суб'єктів організаційно-управлінських відносин буде виправданою тільки в тому разі, коли вона сприяє їхньому всебічному саморозвитку та не порушує ефективності їхньої взаємодії в організаційній системі управління.

Отже, припустимий рівень централізму в системі організаційно-управлінських відносин означає не тільки наявність кількох незалежних спеціальних суб'єктів (наприклад, парламенту й уряду), здатних до взаємного впливу один на одного, але й наявність у громадянського суспільства як суб'єкта організаційно-управлінських відносин необхідної кількості спеціальних і незалежних функцій (тобто визначених меж самостійності), що дозволяють йому впливати на стан цих незалежних спеціальних керуючих суб’єктів, тобто парламенту та уряду. Таким чином, визначені межі самостійності включаються до змісту всіх організаційно-управлінських функцій, котрі входять до управлінського циклу (процесу), що передбачає установлення припустимого рівня централізму, який припускає розподіл цих функцій між всіма керуючими суб'єктами в організаційній систем управління. Причому ступінь розподілу організаційно-управлінських функцій відображає той рівень централізму, що є в тій чи іншій організаційній системі управління.

Однак нижчі суб’єкти організаційно-управлінських відносин, які перебувають у відносинах централізму та піддаються організаційно-управлінському впливу з боку вищого керуючого суб'єкта, завжди прагнуть до звільнення від його впливу, щоб повніше реалізувати свій особливий інтерес. Це означає фактичне звуження організаційно-управлінських функцій у вищого керуючого суб'єкта, або їхнє розширення в нижчого суб' єкта управління, тобто відбувається руйнування меж централізму й розширення меж самостійності.

Цей процес, у своєму крайньому прояві, приводить не тільки до зникнення вищих суб'єктів організації управління, але й до руйну- 
вання відносин централізму, що вказує на абсолютне панування відносин самостійності між керуючими суб'єктами в організаційній системі управління. Відносини абсолютної самостійності в цьому разі, приводять не тільки до порушення балансу взаємодії між керуючими суб'єктами різних рівнів, але й до розпаду самої організаційної системи управління. 3 огляду на це особливості організаційно-управлінської взаємодії керуючих суб'єктів різних рівнів, залежно від стану відносин централізму та самостійності, можна схематично подати у вигляді трирівневої моделі пріоритетно-паритетних зон (рис.1), яка за своїми змістом являє сукупність організаційно-управлінських функцій керуючих суб'єктів, які визначають характер їхньої взаємодії залежно від прав, повноважень і обов'язків у системі організаційно-управлінських відносин.

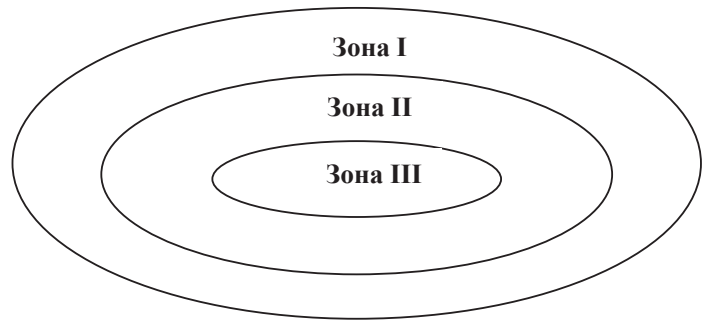

Рис. 1. Трирівнева модель організаційно-управлінських відносин керуючих суб’єктів в організаційній системі управління

Перший рівень цієї моделі (зона I) охоплює головним чином зовнішню зону, що є зоною пріоритету вищого керуючого суб'єкта, в якій йому належить невід'ємне право здійснення однобічного організаційно-управлінського впливу на нижчих суб'єктів, для чого він наділений відповідними правами та повноваженнями. Таким вищим керуючим суб'єктом є, наприклад, уряд країни як центральний орган державної виконавчої влади щодо територіальних органів державної влади. Цей вищий суб'єкт управління за допомогою організаційно-управлінського впливу на нижчих суб'єктів, а також шляхом установлення законодавчо внормованих відносин координує їхню діяльність у різних сферах життєдіяльності суспільства для досягнення загальної мети або реалізації загального суспільного інтересу.

Другий рівень цієї моделі (зона II) є середньою зоною чи зоною паритету, що припускає рівні права та повноваження між взаємодіючими суб'єктами організаційної системи управління різних рівнів. Тобто під час реалізації своїх особливих інтересів вони взаємодіють між собою як рівні партнери. Зміст організаційно-управлінських функцій у зоні паритету, як показує аналіз, є важливим із погляду реаліза- 
ції як загального інтересу, так і особливих інтересів даних суб'єктів. Наприклад, організаційна взаємодія між урядом та органами місцевого самоврядування, інтереси яких перетинаються в межах зони паритету, здійснюється на основі взаємного узгодження їх особливих інтересів. Щодо протиріч між керуючими суб'єктами різних рівнів, то вони розв'язуються не шляхом однобічного придушення інтересів один одного, а шляхом пошуку прийнятних для обох сторін підходів, які враховують як загальносуспільні, так і особливі інтереси кожного 3 них. Тим самим способи реалізації взаємозалежних цілей керуючих суб'єктів у зоні паритету вбирають у себе все різноманіття їхніх інтересів, завдяки чому їхні організаційно-управлінські рішення набувають багатоцільової спрямованості та спираються на взаємну зацікавленість усіх учасників цього процесу, що підвищує ймовірність успішної реалізації як загального, так і особливих інтересів.

Наприклад, уряд для реалізації важливої для суспільства соціальної програми, яка вимагає значних фінансово-матеріальних витрат не може вилучити частину прибутку в органів місцевого самоврядування. Тут потрібна згода громадян та органів місцевого врядування, котрі мають побачити свій особливий інтерес щодо реалізації загальносуспільної програми, щоб активно залучити свої ресурси для її виконання. Таким чином, у зоні паритету відбувається пристосування керуючих суб'єктів різних рівнів до суперечливих ситуацій, що постійно змінюються. Оскільки в мінливих умовах суспільної життєдіяльності має змінюватись не тільки зміст організаційно-управлінських функцій, але й сам механізм їхнього розподілу між керуючими суб'єктами різних рівнів, що не може бути заздалегідь передбаченим під час розмежування їх функціональних зон. Причому самоврядні керуючі суб’єкти, що не «сковані» втручанням зверху, пристосовуються до мінливих ситуацій шляхом пошуку нових способів організаційно-управлінської взаємодії з іншими керуючими суб'єктами. Таким чином, у зоні паритету відбувається узгодження між суб'єктами різних рівнів своїх дій, пошук ефективних шляхів подолання протиріч, а також вироблення раціональних підходів до ухвалення спільних організаційно-управлінських рішень.

Третій рівень моделі (зона III), які охоплює переважно внутрішню зону відповідальності керуючих суб'єктів, є зоною пріоритету, але вже не вищого, а нижчого керуючого суб'єкта. Останній тут повною мірою є самостійним суб'єктом, тобто незалежним від організаційно-управлінського впливу вищого керуючого суб'єкта, оскільки ухвалені ним рішення відображають, як правило, його особливий інтерес. Наприклад, органи місцевого самоврядування звільняються тут від дріб'язкової опіки вищого керуючого суб'єкта та здатні самостійно ухвалювати рішення, зважаючи на специфіку наявних умов, а також максимально співвідносити ці рішення з наявними можливостями та власно сформованими організаційно-управлінськими цілями. 
На практиці кількість функціональних зон організаційно-управлінських відносин керуючих суб'єктів різних рівнів може охоплювати різноманітні варіанти співвідношення пріоритету та napuтету, завдяки чому площа кожної функціональної зони може суттєво змінюватись. Наприклад, якщо звужується функціональна зона вищого керуючого суб'єкта (зона I), а за її рахунок розширюється зона пріоритету нижчого суб'єкта (зона III), то вищий суб'єкт не тільки втрачає своє самостійне значення, але і здатність впливати на нижчих суб' єктів, а також на реалізацію загальної суспільної мети. В цьому разі вищий суб'єкт утрачає важелі організаційно-управлінського впливу на нижчих суб'єктів і перетворюється, таким чином, на координаційний орган організації управління, що забезпечує головним чином координацію спільної діяльності керуючих суб' єктів, але не ухвалює самостійних організаційно-управлінських рішень. До того ж за умов максимального розширення зони незалежності самоврядних суб'єктів (зона III), з одного боку, а також за відсутності інших функціональних зон, з іншого боку, відбувається розпад організаційної системи соціального управління.

Однак за умов паритетної (рівноправної) взаємодії керуючих суб'єктів система організаційно-управлінських відносин між ними починає працювати завдяки узгодженню їхніх особливих інтересів. У цьому разі кожний керуючий суб'єкт максимальним чином впливає на ухвалення організаційно-управлінських рішень, а їхній взаємний вПлив один на одного реалізується в повному обсязі. Завдяки цьому організаційна система соціального управління стає досить гнучкою, але водночас вона втрачає свою оперативність, оскільки унеможливлюється швидкість прийняття взаємоприйнятних рішень між рівноправними керуючими суб'єктами різних ієрархічних рівнів. Такий підхід до побудови організаційно-управлінських відносин міх керуючими суб'єктами є характерним для багатьох організаційних систем управління. Зокрема, він широко використовується в умовах конфедеративного устрою державних утворень, а у федеративних та унітарних державах за цією моделлю головним чином діють представницькі органи державного управління.

Таким чином, максимальна оперативність виконання організаційно-управлінських функцій з'являється тоді, коли зона пріоритету самоврядного суб'єкта (зона III) й зона паритету (зона II) звужуються до мінімуму, а панує абсолютний пріоритет або абсолютний централізм вищого керуючого суб'єкта (зона I). Однак оперативність цього суб' єкта досягається завдяки «виживанню» суспільної системи, оскільки різко зменшується ії̈ здатність до врахування та реалізації особливих інтересів індивідів і соціальних груп, а іiі адаптивні можливості пов'язані 3 пристосуванням до безперервних змін, що відбувається в зовнішньому середовищі. Така оперативність $\epsilon$ виправданою лише в надзвичайних ситуаціях, ліквідація наслідків яких завжди обмежена часовим 
періодом. Отже, залежно від масштабів кожної з функціональних зон, котрі «належать» суб'єктам організаційно-управлінських відносин, змінюється і спосіб їхньої взаємодії в межах організаційної системи управління: від узгодження своїх особливих інтересів до взаємного чи однобічного їх придушення. Внаслідок цього виникає не тільки відповідний тип організаційно-управлінського порядку, але й відповідний тип самої організаційної системи соціального управління. Й хоча те чи інше співвідношення функціональних зон паритету та пріоритету керуючих суб'єктів, їх зміст, склад організаційно-управлінських функцій, прав, повноважень й обов'язків залежить від конкретних особливостей керованого об'єкта, а також від специфіки організаційно-управлінської діяльності (тобто від характеру іiі мети й завдань). Однак досягнення загальної суспільної мети загалом вимагає від керуючих суб'єктів застосування такого організаційно-управлінського принципу, як принцип збалансованого пріоритету.

Натомість аналіз показує, що на практиці відносини централізму та самостійності реалізуються шляхом застосування інших організаційно-управлінських відносин, зокрема таких, як відносини субординації та координації. Відносини субординації не тільки відображають підпорядкованість одного керуючого суб'єкта іншому суб'єкту у процесі керівництва єдиним об'єктом, але й повною мірою забезпечують реалізацію відносин централізму. Відносини субординації між керуючими суб'єктами викликані, з одного боку, необхідністю реалізації загального суспільного інтересу, а з іншого боку, взаємозв'язку загального інтересу з особливими інтересами керуючих суб'єктів різних ієрархічних рівнів. Відповідно до відносин субординації вищі суб'єкти, які відображають загальний інтерес, установлюють згідно із цим інтересом цілі діяльності для нижчих суб'єктів, а також визначають спрямованість дій для всіх інших учасників організаційно-управлінського процесу, що підпорядковані їм за характером виконуваних функцій і завдань [18, с. 90-98].

У найбільш «чистому» вигляді відносини субординації втілюються в основному в лінійних організаційних структурах управління, в яких супідрядність організаційно-управлінських ланок здійснюється за принципом «знизу нагору» та носить характер однозначного вертикального зв'язку. Тобто коли кожний нижчий керуючий суб'єкт контролюється вищим суб'єктом та підпорядковується останньому. Причому організаційно-управлінський вплив вищого суб'єкта здійснюється зверху вниз, за принципом організаційної ієрархії. Така супідрядність буває не тільки між керівними ланками в організаційній системі управління, але й на індивідуальному рівні, тобто між керівниками різних ієрархічних рівнів, а також між керівниками й підлеглими ім працівниками.

Іншим видом структурного розмаїття організаційно-управлінських відносин є відносини керівництва та підпорядкування, котрі 
являють собою відображення субординаційних зв'язків на рівні персоніфікованого керуючого суб'єкта [7, с. 59-64]. Відносини керівництва та підпорядкування реалізуються в організаційно-управлінській практиці за допомогою ще одного виду організаційно-управлінських відносин, такого, як відносини єдиноначальності [16, с. 79]. Відносини єдиноначальності надають керівнику право здійснювати функцію розпорядництва, головним чином за допомогою прямих методів організаційно-управлінського впливу на підлеглих у формі наказів і розпоряджень. Завдяки цим відносинам фактично й відбувається організаційно-управлінська взаємодія керуючих суб'єктів в організаційній системі соціального управління, а також усувається стихійність у діяльності всіх учасників організаційно-управлінського процесу. Водночас кожний керівник за своїм соціальним положенням не тільки відображає загальний інтерес, але й формує мети для підлеглих йому працівників у такий спосіб, щоб вони могли їх реалізувати з урахуванням своїх особливих інтересів. Звідси випливає, що всі суб'єкти організаційно-управлінських відносин,які входять до складу організаційних систем управління, перебувають у тому чи іншому ланцюжку вертикальних субординаційних зв'язків і відносин.

Натомість самостійність керуючих суб'єктів (як самоврядних виразників своїх особливих інтересів) реалізується за допомогою ще одного виду організаційно-управлінських відносин, такого як відносини координаціï. Причому останні характеризують взаємозв'язок несупідрядних керуючих суб'єктів організаційно-управлінської діяльності, зміст яких відображає процес узгодження їх особливих інтересів та сполучення їхніх дій у процесі реалізації власної мети. В межах відносин координації керуючі суб'єкти налагоджують між собою організаційно-управлінську взаємодію відповідно до складності та різноманіття своїх цілей, завдань і видів організаційно-управлінської діяльності. На основі відносин координації встановлюються горизонтальні зв'язки між керуючими суб'єктами, які входять до складу певної системи організаційно-управлінських відносин. Відносини координації встановлюються між окремими суб'єктами, що виконують самостійні організаційно-управлінські функції на різних лініях субординації в межах сукупного керуючого суб'єкта, наприклад, між керівниками державних підприємств однієї чи різних галузей економіки або між керівниками функціональних підрозділів одного чи різних підприємств. Такі координаційні відносини виникають і між іншими незалежними керуючими суб'єктами, зокрема, між керівниками приватних підприємств, лідерами політичних партій, громадських організацій тощо.

На основі координаційних відносин відбувається впорядкування спільних дій, а також формування загальних цілей незалежних суб’єктів управління, котрі будують свої зв'язки за допомогою паритетних відносин. Це дає можливість не тільки здійснювати зіставлення та узгодження тих напрямів діяльності, що відповідають особливим 
інтересам кожного окремого керуючого суб'єкта, але й виробляти єдині підходи до розуміння розв'язуваних завдань, а також оперативно усувати об’єктивно виникаючі між ними протиріччя. Унаслідок цих відносин відбувається взаємне пристосування керуючих суб'єктів один до одного, а також спільне формування загально-групової мети, що виступає організуючим початком не тільки зіставлення їхніх особливих інтересів, але й забезпечення спрямованості спільних дій щодо їх реалізації. Отже, завдяки цим відносинам здійснюється взаємне узгодження особливих інтересів керуючих суб’єктів заради досягнення загальної суспільної мети. Прикладом застосування координаційних відносин може слугувати, наприклад, формування політичних коаліцій чи блоків, пов'язаних із проведенням виборів. У цьому разі перемога того чи іншого кандидата на виборах виступає як групова мета кількох суб'єктів політичного процесу.

Водночас в організаційно-управлінській практиці на основі субординаційних і координаційних відносин (у їх, так би мовити, «чистому» вигляді) можуть утворюватись і змішані види організаційно-управлінських відносин, коли ті ж самі керуючі суб’єкти у процесі реалізації єдиної загальної мети можуть одночасно перебувати між собою у відносинах і субординації, і координації. Причому потреба в утворенні гнучких, адаптивних організаційних структур управління викликана, насамперед, необхідністю використання переваг того чи іншого виду організаційно-управлінських відносин для ефективного досягнення загальної суспільної мети. Субординація забезпечує керуючим суб'єктам оперативність ухвалення та виконання організаційно-управлінських рішень через їх визначену супідрядність, а координація - сприяє гнучкості застосовуваних ними дій у процесі взаємодії з мінливим зовнішнім середовищем. Отже, завдяки сполученню цих двох якостей (оперативності та гнучкості) формуються адаптивні організаційно-управлінські структури, до яких на добровільних засадах уходять формально несупідрядні керуючі суб'єкти, але які підпорядковуються загально-цільовим настановам вищого керуючого суб'єкта, спеціально створюваного ними для ефективного досягнення загальної мети. Таким чином, на відміну від «чистих» координаційних відносин, за яких керуючі суб'єкти самостійно регулюють свої дії, за умови змішаних субординаційно-координаційних відносин, що притаманні адаптивним організаційним структурам управління, такі регулятивні дії здійснюються вищим керуючим суб'єктом. Водночас нижчі суб'єкти зберігають за собою незалежність i, за певної необхідності, можуть самі координувати свої дії, оскільки основним принципом формування змішаних субординаційно-координаційних зв'язків є програмно-цільовий підхід, на основі якого вибудовується програмно-цільова організаційна структура управління [16, с. 370].

Конкретною формою реалізації програмно-цільового підходу на практиці є, наприклад, політичний рух, який має значно більшу сталість 
порівняно з політичною коаліцією, що функціонує, як правило, на «чистих» координаційних зв’язках. Отже, усталене відтворення організаційно-управлінських відносин централізму та самостійності, а також субординації та координації здійснюється не тільки за допомогою організаційно-управлінських впливів між керуючими суб’єктами, котрі визначають цільову спрямованість діяльності, але й за допомогою взаємного організаційно-управлінського впливу, який зумовлює сам процес і результат їхньої організаційно-управлінської діяльності. Такий взаємний вплив, як показує аналіз, здійснюється головним чином завдяки ще одному виду організаційно-управлінських відносин, а саме - відносин дисиипліни та відповідальності [1, с. 273-282].

Відносини дисципліни та відповідальності являють собою взаємозв'язки між керуючими суб'єктами щодо виконання ними взаємних прав і обов'язків у процесі реалізації загальної мети. По суті, відносини дисципліни та відповідальності виступають тут як форма об'єктивної взаємної залежності суб'єктів організаційно-управлінських відносин у межах здійснення спільної діяльності, спрямованої на досягнення загальної суспільної мети. Об'єктивною основою формування відносин відповідальності $\epsilon$, насамперед, особливі інтереси суб'єктів організаційно-управлінських відносин. Адже відносини відповідальності між ними реально існують там і тоді, де й коли керуючі суб'єкти володіють здатністю до взаємного впливу на особливі інтереси один одного, а також коли від рівня виконання прийнятих взаємних зобов'язань залежить реалізація їхніх особливих інтересів. Невиконання або неналежне виконання взаємних зобов'язань часто-густо завдає відчутних збитків їхнім особливим інтересам, i навпаки, якісне виконання взаємних зобов'язань приносить їм заплановану вигоду. Отже, відносини відповідальності, «впливаючи» на особливі інтереси керуючих суб'єктів і сприяючи їх зацікавленості в досягненні загальної мети, є головним чинником механізму взаємного узгодження їхніх особливих інтересів із загальносуспільним інтересом [15, с. 58].

Водночас механізм реалізації відносин відповідальності, як засвідчує аналіз, охоплюють окремі види, форми, принципи й методи, що характеризують певні вимоги до вироблення і здійснення організаційно-управлінських впливів. До видів відповідальності відносять, зокрема, юридичну, політичну, економічну (матеріальну), адміністративну (дисциплінарну), моральну та кримінальну відповідальність. Юридична відповідальність - це відносини між керуючими суб'єктами щодо виконання ними правових норм, що пов'язана із застосуванням установлених законом примусових санкцій, як правило, кримінального та адміністративного характеру. Адміністративна відповідальність, зі свого боку, передбачає встановлення між керуючими суб'єктами визначених відносин, пов'язаних із виконанням делегованих їм функцій та завдань. Основними формами адміністративної відповідальності є насамперед накладання дисциплінарних стягнень або штрафів, пониження в посаді тощо [16, с. 111-112]. 
В основі політичної відповідальності суб'єктів управління лежать такі норми, що регламентують здійснення владних повноважень або функцій. Основними формами політичної відповідальності є такі, як позбавлення депутатських прав, повноважень або займання політичних посад, можливості брати участь у виборах тощо. Матеріальна відповідальність наступає за шкоду, вчинену неправомірними діями або невиконанням чи неналежним виконанням службових обов'язків, а кримінальна відповідальність наступає за вчинення посадових злочинів. Щодо моральної відповідальності, то вона спирається, як правило, на моральні норми, котрі регулюють відносини між людьми в суспільній системі.

Необхідно також підкреслити, що відносини відповідальності виконують у системі організаційно-управлінських відносин низку важливих функцій. Зокрема, за допомогою відновлюваної функиії керуючі суб'єкти повертаються до необхідного стану, встановленого визначеними нормами для тих або інших видів організаційно-управлінської діяльності. За допомогою каральної функиії здійснюється примусовий вплив на тих суб'єктів, котрі наносить їм певного збитку. Превентивна функиія відображає ту роль, яку відіграють відносини відповідальності в попередженні протиправних дій керуючих суб'єктів різних ієрархічних рівнів. Водночас усі функції відносин відповідальності знаходяться між собою в органічному діалектичному зв'язку. Наприклад, каральна функція, що передбачає застосування негативного впливу на особливі інтереси керуючого суб'єкта, забезпечує повернення його протиправних дій до необхідного стану, тобто відновлює необхідний стан організаційно-управлінської діяльності, а також створює умови для використання превентивної функції тощо [10, с. 201-212].

Таким чином, відносини відповідальності як форма об'єктивної залежності керуючих суб'єктів завдають їхнім діям необхідної соціальної спрямованості, оскільки відповідальність одного суб'єкта завжди спрямована у сторону іншого суб'єкта, що визначальним чином впливає не тільки на його положення, але й на його можливості щодо реалізації своїх особливих інтересів. Водночас відносини відповідальності, з одного боку, завжди мають подвійну спрямованість і подвійну залежність одного керуючого суб' єкта від іншого, що виступає ключовою умовою їх ефективної організаційно-управлінської взаємодії в організаційній систем управління. А з іншого боку, для забезпечення ефективності власної діяльності відносини відповідальності керуючого суб'єкта мають бути також спрямованими у сторону керованого об'єкта, виразником інтересів котрого $є$ цей суб'єкт за своїм соціальним положенням.

Водночас аналіз показує, що відносини відповідальності завжди є суперечливими, оскільки ті протиріччя, які лежать в основі організаційно-управлінської взаємодії керуючих суб'єктів, зумовлені їх різноманітними особливими інтересами, наприклад, статусними відмінно- 
стями цих суб'єктів у системі організаційно-управлінських відносин, наявністю в окремих із них егоїстичних і корисливих інтересів, протиставленням своїх особливих інтересів загальним інтересам тощо. В результаті окремі керуючі суб'єкти намагаються перевищити свої права та повноваження, а також відійти від належного виконання своїх професійних обов'язків. Причому ефективне розв'язання цих протиріч відбувається, як правило, на основі взаємоспрямованої відповідальності між керуючими суб'єктами в межах системи організаційно-управлінських відносин. Якщо в цій системі переважає односпрямований характер відповідальності, наприклад, від нижчих до вищих суб’єктів організаційно-управлінських відносин, то порушується сам механізм взаємодії їхніх особливих інтересів. Це, наприклад, може привести до того, що представницькі органи державного управління починають довільно змінювати закони, регулюючи, зокрема, економічну сферу або необгрунтовано втручатись у діяльність підприємств, приймаючи суб'єктивні організаційно-управлінські рішення, оскільки не несуть прямої відповідальності за свої протиправні чи політично ангажовані дії [14, с. 126-128].

Висновки і пропозиції. Отже, розгляд змісту, спрямованості та соціального потенціалу організаційно-управлінських відносин у сучасному соціумі дозволяє зробити наступні висновки.

Соціальні закономірності організаційно-управлінської діяльності в сучасному соціумі зумовлюють не тільки суб'єкт-об'єктний та суб'єкт-суб’єктний характер, але і структуру, зміст, типи соціальні преференції організаційно-управлінських відносин у системах соціального управління різних рівнів. Остання являє собою сукупність взаємозалежних видів організаційно-управлінських відносин, котрі відображають різноманітні форми взаємодії керуючих, спрямованої на виконання ними своїх організаційно-управлінських функцій у процесі реалізації загальної суспільної мети.

Організаційно-управлінські відносини централізму, самостійності, субординації та координації визначають функціональні зв'язки та взаємне положення керуючих суб'єктів, межі їхньої організаційно-управлінської діяльності та характер їх супідрядності в організаційній системі соціального управління. Всі види організаційно-управлінських відносин у перебігу взаємодії керуючих суб'єктів перебувають у нерозривній діалектичній та суперечливій єдності. Водночас співвідношення видів організаційно-управлінських відносин відображає конкретний стан взаємного впливу керуючих суб'єктів один на одного, єдність та відмінність їх особливих інтересів, а також способи їх узгодження в перебігу організаційно-управлінської взаємодії в системі соціального управління.

Залежно від масштабів кожної з функціональних зон, які «належать» суб'єктам організаційно-управлінських відносин, виникає той чи інший спосіб їх взаємодії, зокрема, взаємного чи одностороннього 
придушення або узгодження своїх особливих інтересів, що відповідає певному типу соціально-управлінського порядку в організаційній системі соціального управління. Визначальним принципом формування структури організаційно-управлінських відносин у системі взаємодії керуючих суб'єктів із погляду досягнення ними загальної суспільної мети, є принцип збалансованого пріоритету цих відносин.

Процес і результат реалізації суб'єктами організаційно-управлінських відносин своїх організаційно-управлінських функцій зумовлені станом розвитку відносин відповідальності, котрі $є$ не тільки формою соціальної залежності керуючих суб'єктів, але й механізмом їх взаємного узгодження загального та особливих інтересів. 3 огляду на принципи необхідності та достатності, відповідності та соціальної спрямованості відносин відповідальності визначаються вимоги до функціонального призначення керуючих суб'єктів у межах організаційної системі соціального управління, а також механізми поділу між ними видів відповідальності, iіi величини та спрямованості.

Загалом різні види організаційно-управлінських відносин характеризують взаємозумовлену сукупність зв'язків між елементами організаційної системи соціального управління, котрі забезпечують ііі відтворення та розвиток як цілісного соціального організму. Наприклад, реалізація відносин централізму неможлива без установлення відносин субординації, а реалізація відносин самостійності - без установлення відносин координації.

Підтримання належного стану функціонування організаційно-управлінських відносин залежить від стану відносин відповідальності, оскільки єдність відносин централізму та самостійності, а також відносин субординації та координації реалізується тим ефективніше, чим ефективніше поділені види відповідальності між суб'єктами організаційно-управлінських відносин, а також їхня величина і спрямованість. Тим самим структура цих відносин виступає як комплекс об'єктивних взаємозв'язків, які відображають істотні параметри соціально-управлінського порядку в організаційній системі соціального управління, а також зумовлюють соціальний зміст загальної мети та узгоджені дії керуючих суб'єктів, спрямовані на реалізацію як загального, так і особливих інтересів.

\section{Список використаної літератури}

1. Афанасьев В.Г. Человек в управлении обществом. Москва : Политиздат, 1977. $382 \mathrm{c}$.

2. Бех В.П., Грицяк І.А., Ребека О.Г. Фантом планетарного організму: погляд у майбутнє: монографія. Київ : «МП Леся», 2015. 500 с.

3. Бех Ю.В. Філософія управління соціальними системами: монографія. Київ : Вид-во НПУ імені М.П.Драгоманова, 2012. 623 с.

4. Булыгин Ю.Е., Волковский В.И. Основы теории организации социального управления. Москва : ЧеРо. 2000. 143 с. 
5. Введение в управление / под. ред. В.Н. Иванова. Москва : АНСТМСУ, $2002.358 \mathrm{c}$.

6. Галушка И. Управление экономикой. Москва : Прогресс, 1985. 286 с.

7. Рапопорт В.С., Дулькин М.3. Организация систем управления. Москва : АНХ Совета Министров СССР, 1986. 135 с.

8. Слепенков И.М., Аверин Ю.П. Основы теории социального управления. Москва : Высш. шк., 1990. 302 с.

9. Словарь-справочник менеджера / под ред. М.Г. Лапусты. Москва : ИНФРА-М, 1996. 608 с.

10. Теория управления : энциклопедический словарь / под ред. В.Н. Иванова. Москва : Муниципальный мир, 2004. 672 с.

11. Толковый словарь по управлению. Москва : Аланс, 1994. 252 с.

12. Туленков М.В. Організаційна взаємодія в системах соціального управління (соціологічний аналіз) : монографія. Київ : ІПК ДСЗУ, 2005. 222 с.

13. Туленков М.В. Організаційна впорядкованість систем соціального управління (модель соціологічного аналізу): монографія. Київ : ІПК ДСЗУ, 2006. 102 с.

14. Туленков М.В. Теоретико-методологічні основи організаційної взаємодії в соціальному управлінні: монографія. Київ : Каравелла, 2018. 512 с.

15. Управління людськими ресурсами: понятійно-термінологічний словник /за ред. Г.В. Щокіна та ін. Київ : МАУП, 2006. 496с.

16. Управление персоналом: энциклопедический словарь / под ред. А.Я. Кибанова. Москва : ИНФРА-М, 1998. 456 с.

17. Управління сталим розвитком: підручник / за заг. ред. В.П. Беха, М.В. Туленкова. Київ : Каравела, 2018. 538 с.

18. Хан С.М. Управленческие отношения социализма. Москва : Наука, 1982. $208 \mathrm{c}$.

19. Централизм и самостоятельность: поиски решения. Москва : Наука, 1990. $198 \mathrm{c}$.

Tulenkov M. V., Bech V. P. Organizational and management relations in the focus of sociological analysis

The article in the context of systemic sociological analysis considers the process of forming the social potential of organizational and managerial relations in a modern transitional society. At the same time, the basic principles, content parameters, functional nature and specific features of various types of organizational and managerial relations are determined, preconditions and key social factors of conceptual evolution and development of these relations are singled out, and mechanisms of functioning and reproduction of certain types of organizational and managerial relations object-object interaction in the process of various social activities at different levels of social organization of modern society. In particular, the conditions for the use of such types of organizational and managerial relations as arguments such as relations of leadership and subordination, subordination and coordination, centralism and independence, discipline and responsibility, etc. are argued.

It is determined that one of the main types of organizational and managerial relations is the relationship of centralism and independence, which exist among themselves in an inseparable and contradictory dialectical unity. Moreover, the 
relationship of centralism is a form of relationship between the subjects of management of different organizational levels on the implementation of certain functions, in which one subject of management (superior) is endowed with the rights and powers to determine content and direction of another entity (subordinate) in accordance with the general management goal, ie in accordance with the general interest. As for the relationship of independence, they assume that the subjects of organizational and managerial relations have such rights, powers and responsibilities that allow them to determine content and direction of their activities. If in the relations of centralism the superior subject of organizational and managerial relations acts as a monopoly subject, the influence of which is mostly one-way, then in the relations of independence all subjects regardless of the level of social hierarchy are equal, ie their relationship is based on mechanisms of mutually directed organizational and managerial influence on each other.

The article also analyzes the practice of applying different types of organizational and managerial relations in functioning of social organizations in various spheres of public life, and offers relevant recommendations for restructuring organizational and managerial relations in the context of global socio-economic, political and sociocultural changes. the course of social transformations of modern Ukrainian society on the basis of the principles of democracy and the free market.

Key words: content, features, nature and potential of organizational and managerial relations, typology and functions of organizational and managerial relations, mechanisms of formation, functioning, reproduction and development of organizational and managerial relations. 